\title{
CORRIGENDUM
}

\section{Altered parvalbumin basket cell inputs in the dorsolateral prefrontal cortex of schizophrenia subjects}

JR Glausier, KN Fish and DA Lewis

Molecular Psychiatry (2014) 19, 140; doi:10.1038/mp.2013.177; published online 3 December 2013

Correction to: Molecular Psychiatry advanced online publication,

12 November 2013; doi:10.1038/mp.2013.152

Following the publication of the above article, the authors noticed that the Acknowledgments section was missing the funding sources. The omitted information appears below:

\section{ACKNOWLEDGMENTS}

This work was supported by NIH grants MH088160 to JRG; MH096985 to KNF; and MH084053 and MH043784 to DAL. 